\title{
RESENHA
}

DOI: http://dx.doi.org/10.1590/So034-759020170208

\section{NEGOCIAÇÕES COLETIVAS E RELAÇÕES DE TRABALHO NO BRASIL}

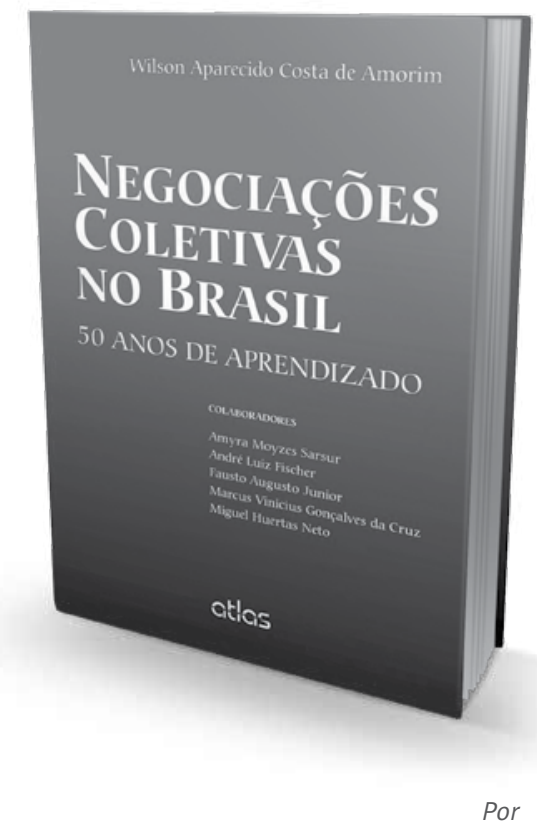

MARCO ANTONIO GONSALES DE OLIVEIRA professormarcogonsales@gmail.com Doutor em Administração de Empresas pela Pontifícia Universidade Católica de São Paulo, Faculdade de Economia, Administração, Contábeis e Atuariais - São Paulo - SP, Brasil

\section{NEGOCIAÇÕES COLETIVAS NO BRASIL: 50 ANOS DE APRENDIZADO.}

Wilson Aparecido Costa de Amorim (Org.). São Paulo, SP: Atlas, 2015. 232 p.

O livro Negociações coletivas no Brasil: 50 anos de aprendizado é o resultado de um precioso trabalho de pesquisa do grupo de Gestão de Recursos Humanos e Mercado de Trabalho da FEA USP, coordenado pelo professor Dr. Wilson Aparecido Costa de Amorim. Além dos 50 anos das negociações coletivas (NC) no Brasil, outras abordagens sobre a área das relações de trabalho (RT) também são apresentadas. 0 livro enfatiza a importância da atual institucionalização das NC no Brasil, assim como 0 amadurecimento nas RT entre empresas, trabalhadores e o Estado. A análise fundamenta-se no conceito de sistema de RT desenvolvido por John Thomas Dunlop em 1958 (Dunlop, J. T. [1993]. Industrial relations systems. Cambridge, USA: Harvard Business School Press (lassic).

A primeira parte é destinada à periodização, revisão e contextualização dos 50 anos de NC no Brasil. Na segunda parte, os autores debatem e apontam resultados de pesquisas sobre temas substanciais, como a internacionalização dos sindicatos, as peculiares características setoriais do sistema nacional - bancários, metalúrgicos e transportes coletivos urbanos, além das abordagens sobre recursos humanos e mercado de trabalho.

O capítulo 1 discorre sobre as NC brasileiras que ressurgiram como elemento fundamental na vida econômica e política do País no período militar, entre 1964 e 1985. Analisa as barreiras existentes ao desenvolvimento da NC e as formas de superação encontradas pelos sindicatos nesses anos.

Dando continuidade à história das NC, o capítulo 2 faz um retrospecto do período de redemocratização (de 1986 até o fim dos anos 1990) sob o pano de fundo econômico e os efeitos sobre o emprego e a remuneração.

O capítulo 3 aborda as NC no Brasil após o ano 2000, período caracterizado pela elevação do poder de barganha dos sindicatos e consequente crescimento do número de acordos coletivos prevendo aumentos reais para os trabalhadores. 
O capítulo 4 faz uma análise utilizando dados sobre os processos grevistas privados no período entre 2009 e 2012 e discorre sobre o grau de amadurecimento das partes na condução de NC no âmbito das RT no Brasil. A obra destaca que, a partir de 2003, houve crescimento econômico, o desemprego reduziu-se, o salário mínimo cresceu, a formalização e a contribuição com a previdência social aumentaram, assim como ocorreu o aumento do rendimento real e da massa de rendimento real. Não obstante, os movimentos grevistas também cresceram no período, principalmente a partir de 2009, e continuaram a tendência crescente mesmo com uma economia menos aquecida.

O capitulo 5 tem como objetivo compreender os movimentos de mudança dos sindicatos para enfatizar a cooperação sindical internacional, no cenário da globalização dos mercados, como o próprio autor destacou. A desregulamentação da contratação do trabalho por meio dos mercados, a partir de 1970, tornou-se predominante, e os sindicatos procuraram inovar dando maior atenção aos locais de trabalho, à aproximação dos movimentos sociais dos jovens, dos imigrantes e das mulheres, à ampliação dos serviços, à formação técnica dos trabalhadores e, principalmente, à internacionalização.

O capítulo 6 faz uma revisão sobre as mudanças nas estruturas das NC do setor metalúrgico paulista na década de 1990 , período marcado pela entrada brasileira na economia globalizada e pela transformação da estrutura produtiva a partir de uma nova lógica de produção - a competitividade. Não obstante, o símbolo desse período foi a flexibilização do salário - a sua indexação aos resultados - por meio da criação, ou da substituição, das políticas salariais às práticas das PLR. No setor metalúrgico, o objetivo da unificação da data-base para novembro, almejado pelos trabalhadores nos anos 1980, foi conquistado, e as comissões de fábricas avançaram e concretizaram a experiência da negociação descentralizada.

O capítulo 7 apresenta as características e tendência observadas nas NC no setor bancário brasileiro no período recente. Os bancários fazem da sua categoria uma das mais tradicionais da classe trabalhadora. A patronal, mesmo discreta, sempre foi bastante ativa. $O$ autor aponta para o amadurecimento das partes em termos das RT. Enfatiza a baixa participação da justiça do trabalho nas negociações e as inovações com mesas de debate sobre igualdade, gênero, assédio moral, entre outras.

0 setor dos transportes coletivos urbanos se estabelece em um contexto institucional bem mais complexo na dimensão das RT. 0 capítulo 8 traz elementos para uma discussão sobre as greves nesse setor e propõe uma reflexão sobre o futuro das NC. Os recentes conflitos sociais relacionados a esse setor elevaram os passageiros - clientes - a interlocutores na discussão sobre o transporte. As greves propositivas, com ênfase na re- muneração, não obtiveram os resultados que outras categorias conquistaram. Não podendo ser diferente, as greves do setor ultrapassam a capacidade de medição dos sindicatos. São desdobramentos complexos que envolvem prefeitura, população, trabalhadores, empresas, justiça e movimentos sociais diversos. Um modelo em que, segundo o autor, há, invariavelmente, uma situação de perde-perde, para a qual propõe uma urgente institucionalização das mesas de negociações.

O capítulo 9 introduz ao debate a área de recursos humanos, revisitando dois artigos: o primeiro, das pesquisadoras brasileiras Maria Tereza L. Fleury e Rosa M. Fisher (1992), e o segundo, do pesquisador norte-americano Bruce E. Kaufman (2010). Respectivamente, um debate sobre as principais correntes - nos campos da administração e das ciências sociais - sobre a área e as pesquisas sobre RT, e uma crítica ao modelo neoliberal, junto a uma proposta em nome do trabalho.

0 assunto prossegue no capítulo 10 com a análise - resultado de pesquisa qualitativa entre 2010 e 2012 - das RT e da gestão por competência sob o olhar dos sindicatos como representantes dos trabalhadores. Como esperado, os sindicalistas têm pouco ou quase nenhum conhecimento da ferramenta de gestão por competência, e, por outro lado, observa-se que a prática não é realizada em toda a organização, sendo limitada a alguns níveis hierárquicos. Segundo o autor, o modelo de gestão por competência pode caracterizar-se como um entrave na relação entre o sindicato e o trabalhador, principalmente pelo caráter individualizante da prática.

O livro finaliza no décimo primeiro capítulo com uma breve descrição e reflexão da formação do mercado de certificação bancária no Brasil, a partir da introdução de mecanismos de regulação estabelecidos pelo Banco Central do Brasil (Bacen) e reforçados pelos próprios bancos. A certificação tornou-se indispensável para o emprego do bancário, no entanto os cursos são oferecidos pelos sindicatos patronais, nos quais tanto o trabalhador bancário quanto o sindicato não estão presentes.

A institucionalização das NC no Brasil demonstra o amadurecimento no âmbito das RT entre empresas, trabalhadores e Estado. As NC contribuíram, principalmente nos países centrais, como importante ferramenta de regulação social, sendo uma alternativa aos reajustes salariais impostos pelo mercado. Por outro lado, garante às empresas a estabilidade e a previsibilidade das RT, o que nem sempre é favorável ao trabalhador e, portanto, ao equilíbrio do sistema. Faltou ao livro uma avaliação crítica sobre as NC no Brasil. Diante da evidente predominância dos baixos salários que caracteriza o mercado de trabalho brasileiro (principalmente no âmbito da produção), as NC, ao padronizarem o sistema, não acabam por limitar possíveis maiores reajustes salariais aos trabalhadores? 